\title{
Collective Identity Changes in Far-right Online Communities: The Role of Offline Intergroup Conflict
}

\author{
Ana-Maria Bliuc, Western Sydney University \\ John Betts, Monash University \\ Matteo Vergani, Deakin University \\ Muhammad Iqbal, Victoria University \\ Kevin Dunn, Western Sydney University
}

\begin{abstract}
The role of online communities in shaping behaviours 'in real life' (IRL) is well-established, however, less is known about how such communities are affected by offline events. Thus, we investigate here the ways in which the collective identity of a far-right online community is affected by offline intergroup conflict. That is, we examine over 14 years of online communication between members of a national division of the global white supremacist community Stormfront.org. We analyse members' language use and discourse before and after significant intergroup conflict in 2015, that is, local racist riots in Sydney, Australia. We found that the riots were associated with significant changes in the collective beliefs of the community (as captured by members' most salient concerns and group norms), emotions and consensus within the community. Overall, the effects of the local riots were manifest in a reinvigorated sense of purpose for the far-right community with a stronger anti-Muslim agenda.
\end{abstract}




\section{Collective Identity Changes in Far-right Online Communities: The Role of Offline Intergroup Conflict}

\section{Introduction}

We live in a networked world where online communities are increasingly impactful 'in real life' (IRL); most obviously, they enable people globally to connect under shared ideologies and mobilise to achieve collective goals regardless of geographical distances and national borders (Wojcieszak, 2010). Many of these ideologically-driven communities function by nurturing networks of supporters who share the aim of achieving social change through commitment to a common cause (such as gun control, animal rights, marriage equality, etc.). The impact of online communities in the real-world has been extensively studied; for instance, we have evidence that engagement with online communities affects interpersonal relationships, personal empowerment, and recovery capital in online communities of support (Barak et al., 2008; Best et al., 2018; Bliuc et al., 2017; Ishii and Ogasahara, 2006).

Engagement in politically-driven online communities was also shown to be connected with 'offline' collective action (Alberici et al., 2016; Lee et al., 2017; McGarty et al., 2014; Odağ et al., 2016). However, we know far less about the potential effects of significant sociopolitical events 'in real life' on online communities. In particular, in the domain of politics, we have recently witnessed a global reinvigoration of the far-right movement, arguably aided by online communication both within (ideologically-driven) online communities and between these communities and their supporters (Awan, 2014; Bliuc et al., 2018b; Jakubowicz et al., 2017; Lawrence and Boydstun, 2017; Oksanen et al., 2018; Zhang et al., 2017). That is, the popularity of far-right political groups in Western democracies have been steadily on the rise, with many of these groups moving to mainstream politics through winning parliamentary representation in Western nations such as Australia, Netherlands, France, Austria, Denmark, and Sweden (Bos, et al., 2017; Inglehart \& Norris, 2016).

Thus, in this research, we focus on examining associations between events 'in real life' and the internal dynamics of online communities from the extreme of the political spectrum. In particular, we examine how far-right online communities may be affected by historical significant socio-political events underpinned by intergroup conflict. To test whether and how such events are associated with the socio-psychological processes in farright online communities, we examine changes occurring over a period of 14 years in the collective identity of Stormfront Downunder, the Australian division of the major global white supremacist community Stormfront.org. In Australia, Stormfront Downunder has been for a long time a key online communication channel for the far-right movement and their sympathisers (Jakubowicz et al., 2017). By collective identity, in this instance we refer to the specific social identity content (including beliefs, values, norms and attitudes) associated to a group membership (Livingstone and Haslam, 2008) which implies difference in how we see the world rather than how we are (in terms of fixed social categories that define us).

We focus on Stormfront because it constitutes one of the most influential far-right online communities in the world with branches in Europe, South Africa and Australia; 
notably, notorious far-right terrorists Anders Breivik (responsible for the 2011 Norway attacks) and Dylann Roof (responsible for the 2015 South Carolina attack) were linked to Stormfront. More recently, in August 2017, Stormfront.org was shut-down in response to the violence during the Unite the Right rally in Charlottesville, Virginia, which resulted in the death of one counter-protester (Southern Poverty Law Centre, 2017). While the offline impact of Stormfront is well-evidenced (see also Beirich, 2015), there is no research directly investigating how significant socio-political events 'in real life' may impact this powerful online community.

From a theoretical viewpoint, in the field of intergroup relations, how groups create and transform the content of their collective identities is not very well-understood (Turner et al., 2001). From research on opposing groups formed around mutually exclusive beliefs about how the world should be - opinion-based groups such as climate change sceptics and believers or supporters of political opponents (Bliuc et al., 2007; 2015; 2018a; Postmes, 2015), we know that intergroup conflict can increase group commitment. Thus, in a sense, groups are empowered by conflict with opposing groups. Applying these ideas to online communities, we go beyond investigating increased group commitment as an outcome of intergroup conflict to examine whether intergroup conflict 'in real life' is associated with changes in the collective identity of the online far-right community Stormfront Downunder. In this case, we focus on the Australian context for two main reasons. First, in this particular setting of Australian politics, we have a clear case of pronounced intergroup conflict which is of significance for the local far-right community: the Cronulla Race Riots which occurred in Sydney in December 2005. The riots represent a powerful illustration of sharp ideological division and intergroup conflict (Bliuc et al., 2012). As the variations in levels of online activity in Stormfront Downunder illustrated in Figure 1 show, the 2005 riots coincide with a significant reinvigoration of the online community with an increased number of people joining at that point and immediately after. The number of posts per week on the forum stayed at levels significantly higher than the pre-riots levels for a long period of time (taking approximately 3 years to return to the pre-2005 levels).

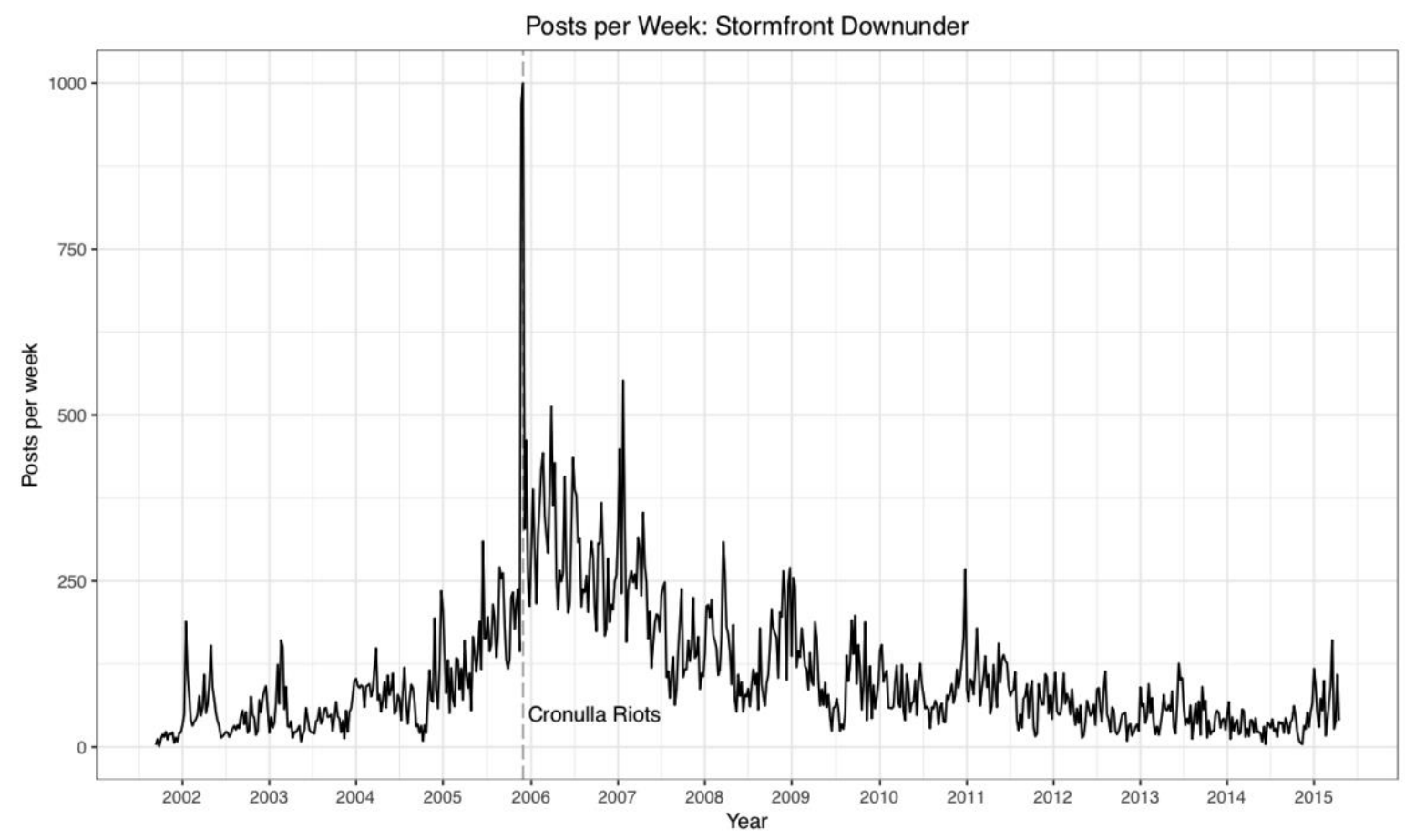


Figure 1. Weekly activity levels in Stormfront Downunder forum $(2001-2015)$ reveals peak members' activity in the aftermath of the local race riots.

To identify change over time in the collective identity of Stormfront Downunder, we examine the evolution of collective beliefs and emotions between 2001, when the online community was formed in Australia, and 2015, a decade after the race riots, as reflected by several indicators. Thus, we consider group members' concerns and group norms (representing the collective beliefs of the online community) as emerging from the communication between members, collective emotions in the community and levels of consensus within the community.

Group concerns, norms, emotions and consensus are captured by analysing communication before and after the Cronulla race riots (pre- and post-December 2005). We seek to establish whether the effects of the riots go beyond changes in members' levels of engagement in the online community (as captured by increased activity levels illustrated in Figure 1), in the particular political context of Australia at that time; we predict that the local race riots would produce changes in the collective beliefs of the online community - captured as focus on particular concerns and content of group norms and mirrored by corresponding changes in emotions and levels of consensus within the community.

\section{Stormfront as an ideologically-driven online community}

We propose that communities such as Stormfront are essentially opinion-based groups - that is, psychological groups formed around a shared opinions, ideologies or worldviews (Bliuc et al. 2007; 2015; 2018a). The collective identities of people identifying with these communities are derived from specific versions of a national identity, but which are based on an ideological view characterised by the justification of white privilege and associated values. Previous research in Australia showed that the Cronulla race riots were crucial in the rhetorical activation of national identity among White supremacists (Dunn 2009; Noble, 2009; Noble and Poynting, 2010). The Cronulla Riots were a key moment in racist politics of Australia. At the time, people of non-Anglo appearances, who happened to be in the Cronulla area, were abused and bashed by angry white (mostly young male) crowds. The young appropriated songs and icons of Anglo-ness, and through these performances, a racially privileged nationalism was asserted. The first riot was followed by subsequent incivility by a handful of Lebanese-Australian youths, as retaliatory responses, and this provided great material for racialised media attacks (Dunn, 2009). The official inquiry into the riots blamed media coverage, especially talk radio, for inciting and inflaming local tensions into this nationally shocking event. In keeping with an earlier refusal to condemn racist politics (antiAsian in that case) the Australian Prime Minister, John Howard, denied that the riots were racist acts.

In the current research, we use the race riots as a reference point in our analysis. We propose that they represent a clear illustration of intergroup conflict between two ideologically-driven groups, broadly defined as supporters and opponents of multiculturalism in Australia. The group consisting of opponents of multiculturalism (or supporters of the riots) is ideologically aligned to the online community Stormfront Downunder, which means that the riots likely represent a significant intergroup conflict for the online community that we study.

\section{Political context}

In this article, our aim is to track not just the rate of activity and what it indicates about breadth of association in the online community, but also examine changes in collective 
social psychological indicators as reflected in the nature of the online contributions. These changes are examined in relation to the local race riots which in turn occurred in particular socio-political context. Specifically, the riots represent a materialisation of a political climate in which racist politics had been achieving unheralded success within Australian mainstream politics. From the mid-1990s the leader of the nationalistic One Nation Party, Pauline Hanson had achieved electoral success in the Federal Parliament (in a lower house seat) and even more success in the Queensland State Parliament. The One Nation Party had deployed a particularly anti-Asian theme in their political rhetoric, eschewing the more traditional farright emphasis on Jews and Blacks. They referred to ghetto formation and cultural incompatibility and de-emphasised 'race' per se, as was typical of the emerging new racist movements globally (Dunn, 2009). This reveals the constructed and dynamic foci of racist political movements. When Pauline Hanson came to power, the Australian Prime Minister at the time (John Howard) did not condemn her racist attacks on Asian-Australians and this was indicative of a growing permissiveness around overt and stridently racist political and media commentary which later inflected with anti-Muslim attacks (overtly deployed for assumed political gain, and strongly supported by sections of the tabloid and 'infotainment' media). A decade later, Pauline Hanson re-entered the Australian Parliament, as a Senator for the State of Queensland, and made exactly the same maiden speech as a decade before, only swapping the words "Asian" for "Muslims". She was tapping into the emerging Islamophobia in western nations and using new racist arguments that she had seen as successful ten years before (Briskman, 2017; Kamp et al., 2017).

\section{Current Study}

We analyse the language used in online social interactions by members of the online community in the form of their posts and comments on the forum from 2001 to 2015. Thus, all user posts to the Stormfront Downunder (https://www.stormfront.org/forum/f38/) from 2001 to 2015 were extracted for the analysis. In total 75,795 posts were analysed, comprising of 73,275 member posts and 2,520 anonymous posts (made under 5,489 threads). The data extracted from each post consisted of a user identifier (or anonymous), thread identifier, temporal stamp (time and date), and textual content.

Our research design aims at identifying differences in the language use and discourse in the online community Stormfront Downunder before and after local race riots. We use both quantitative and qualitative methods to examine the changes in collective identity of the community as expressed in members' communication in the form of the main concerns of the group and group norms. In addition to these indicators, we also investigate emotions and levels of consensus in the community. Specifically, we examine three language functions as described in Table 1.

Table 1. Study design: methodological approach, research techniques and samples.

\begin{tabular}{llll}
\hline $\begin{array}{l}\text { Function of } \\
\text { the language }\end{array}$ & $\begin{array}{l}\text { Object of the } \\
\text { analysis }\end{array}$ & $\begin{array}{l}\text { Technique used in } \\
\text { the analysis }\end{array}$ & Sample \\
\hline $\begin{array}{l}\text { Collective } \\
\text { beliefs as main } \\
\text { concerns of } \\
\text { the group }\end{array}$ & $\begin{array}{l}\text { Most } \\
\text { frequently } \\
\text { used nouns } \\
\text { before and } \\
\text { after the riots }\end{array}$ & $\begin{array}{l}\text { Natural Language } \\
\text { Processing (NLP) } \\
\text { approach consisting of }\end{array}$ & $\begin{array}{l}\text { Posts and comments before and after the } \\
\text { riots } \\
\text { comparing the most } \\
\text { used nouns before and } \\
\text { after the riots }\end{array}$ \\
\end{tabular}




\begin{tabular}{|c|c|c|c|}
\hline $\begin{array}{l}\text { Collective } \\
\text { beliefs as } \\
\text { group norms }\end{array}$ & $\begin{array}{l}\text { Context and } \\
\text { content of the } \\
\text { posts before } \\
\text { and after the } \\
\text { riots }\end{array}$ & $\begin{array}{l}\text { Qualitative thematic } \\
\text { analysis }\end{array}$ & $\begin{array}{l}\text { The } 100 \text { most quoted posts in the forum } \\
\text { between } 2001 \text { and } 2015 \text {. Our decision to } \\
\text { analyse the top quoted posts is based on } \\
\text { the assumption that these posts are likely } \\
\text { to capture content that is central to the } \\
\text { group's collective identity; these posts } \\
\text { are drivers of intra-group interaction, so } \\
\text { they are likely to reflect the } \\
\text { development and change occurring in } \\
\text { the group's normative content. }\end{array}$ \\
\hline $\begin{array}{l}\text { Emotions and } \\
\text { levels of } \\
\text { consensus) }\end{array}$ & $\begin{array}{l}\text { All elements } \\
\text { of the } \\
\text { language } \\
\text { (including } \\
\text { nouns, verbs } \\
\text { and function } \\
\text { words) }\end{array}$ & $\begin{array}{l}\text { Computerised } \\
\text { linguistic analysis } \\
\text { using Linguistic } \\
\text { Inquiry Word Count } \\
\text { (LIWC, Pennebaker et } \\
\text { al., 2007; 2015) }\end{array}$ & $\begin{array}{l}\text { Posts and comments published } 6 \text { months } \\
\text { before and } 6 \text { months after the riots. }\end{array}$ \\
\hline
\end{tabular}

\section{Results}

\section{Main concerns of the online community}

Based on the analysis of changes in word usage, the riots seem to mark a clear qualitative transformation in the main concerns of the community members. Before the riots, language use reveals a focus on topics of discussion typical of white supremacist communities worldwide. This includes discussions around 'being white', that is, race and colour, the Jewish people, women and government, as well as around anti-Black and anti-Asian content. This is evidenced in Table 2, which shows the most frequently used nouns in the timeframe commencing at the beginning of the forum in 2002 through to the end of December 2005 (the date of the riots). By contrast, comparing language use before and after the riots, the focus on the geographic location of the riots, Cronulla (and the beach) and the prominence of concerns with specific ethnic groups and especially followers of Islam becomes evident. Table 3 shows the 50 most frequently used nouns having the greatest proportional change in use from the 6 months pre-riots to the 6 months post-riots. Average word frequency pre- and post- riots as well as during the week of the riots are shown.

Table 2. The 50 most frequently used nouns occurring in the forum (excluding common speech) prior to the riots ordered by rank. Variants of some nouns have been grouped as indicated, *included aussies

\begin{tabular}{llllllllll}
\hline Rank & Noun & Rank & Noun & Rank & Noun & Rank & Noun & Rank & Noun \\
\hline 1 & white(s) & 11 & asian(s) & 21 & war & 31 & population & 41 & national \\
2 & australia(n)(s)* & 12 & women & 22 & things & 32 & children & 42 & media \\
3 & people & 13 & work & 23 & live & 33 & society & 43 & help \\
4 & jew(s)(ish) & 14 & government & 24 & men & 34 & sydney & 44 & immigration \\
5 & country(ies) & 15 & thing & 25 & nation & 35 & problem & 45 & family \\
6 & time & 16 & day & 26 & life & 36 & thought & 46 & racial \\
7 & world & 17 & fact & 27 & place & 37 & year & 47 & european \\
8 & race & 18 & man & 28 & culture & 38 & point & 48 & power \\
9 & years & 19 & something & 29 & money & 39 & hope & 49 & someone \\
10 & black(s) & 20 & anyone & 30 & anything & 40 & support & 50 & group \\
\hline
\end{tabular}




\begin{tabular}{llllllllll}
\hline Word & $\begin{array}{l}\text { Pre- } \\
\text { Riots }\end{array}$ & $\begin{array}{l}\text { Riot } \\
\text { Week }\end{array}$ & $\begin{array}{l}\text { Post } \\
\text { Riots }\end{array}$ & Increase & Word & $\begin{array}{l}\text { Pre- } \\
\text { Riots }\end{array}$ & $\begin{array}{l}\text { Riot } \\
\text { Week }\end{array}$ & $\begin{array}{l}\text { Post } \\
\text { Riots }\end{array}$ & Increase \\
\hline cronulla & 0.04 & 190 & 20.04 & 521.00 & immigration & 5.00 & 48 & 16.42 & 3.28 \\
anglo & 0.38 & 11 & 14.31 & 37.20 & forum & 2.81 & 19 & 9.19 & 3.27 \\
flag & 1.23 & 67 & 21.50 & 17.47 & media & 6.85 & 160 & 21.85 & 3.19 \\
leb(s)(anese) & 2.77 & 364 & 41.81 & 15.10 & news & 3.42 & 68 & 10.88 & 3.18 \\
greeks & 0.81 & 30 & 11.19 & 13.86 & north & 2.27 & 12 & 7.15 & 3.15 \\
pride & 2.38 & 45 & 15.27 & 6.40 & yeah & 3.96 & 25 & 12.46 & 3.15 \\
nsw & 1.58 & 19 & 9.73 & 6.17 & please & 3.96 & 27 & 12.38 & 3.13 \\
movie & 1.69 & 3 & 10.19 & 6.02 & chinese & 2.88 & 1 & 8.88 & 3.08 \\
eastern & 1.81 & 93 & 9.65 & 5.34 & lets & 3.46 & 37 & 10.23 & 2.96 \\
smoking & 1.62 & 2 & 8.54 & 5.29 & racism & 2.65 & 30 & 7.81 & 2.94 \\
violence & 1.73 & 92 & 8.92 & 5.16 & local & 3.19 & 21 & 9.35 & 2.93 \\
police & 6.42 & 184 & 30.42 & 4.74 & forget & 2.38 & 10 & 6.81 & 2.85 \\
middle & 2.77 & 97 & 12.92 & 4.67 & muslim(s) & 19.19 & 134 & 54.27 & 2.83 \\
islam(ic) & 4.96 & 28 & 22.23 & 4.48 & aboriginal(s) & 10.54 & 12 & 29.69 & 2.82 \\
beach & 1.46 & 88 & 6.27 & 4.29 & culture & 8.38 & 32 & 23.65 & 2.82 \\
stuff & 2.92 & 16 & 11.88 & 4.07 & evil & 2.38 & 9 & 6.73 & 2.82 \\
aussie(s) & 13.65 & 344 & 53.92 & 3.95 & read & 6.35 & 25 & 17.88 & 2.82 \\
ethnic & 2.88 & 23 & 11.12 & 3.85 & community & 4.12 & 46 & 11.50 & 2.79 \\
gangs & 1.92 & 66 & 7.27 & 3.78 & within & 3.19 & 30 & 8.81 & 2.76 \\
link & 1.88 & 17 & 7.00 & 3.71 & scum & 2.73 & 87 & 7.50 & 2.75 \\
attacks & 1.88 & 29 & 6.92 & 3.67 & especially & 3.65 & 18 & 9.96 & 2.73 \\
europe & 4.12 & 44 & 14.38 & 3.50 & general & 2.54 & 38 & 6.92 & 2.73 \\
multiculturalism & 4.54 & 39 & 15.81 & 3.48 & came & 5.23 & 39 & 13.92 & 2.66 \\
freedom & 2.23 & 19 & 7.69 & 3.45 & happened & 3.27 & 31 & 8.58 & 2.62 \\
game & 3.96 & 3 & 13.38 & 3.38 & soon & 2.62 & 23 & 6.85 & 2.62 \\
& & & & & & & & & \\
\hline
\end{tabular}

Table 3. The 50 words having the greatest proportional increase in use during the 6 months before and after the riots, ranked by increase. Average word frequency per week is shown pre- and post-riots as well as for the week of the riots. Word variants have been grouped as indicated.

The focus on the riots is evidenced by the prevalence of the term 'Cronulla' which was used 190 times during the week of the riots and approximately 20 times per week, on average, after the riots. Other words showing significant increases in usage also reflect higher concerns with race, religion and culture. The key cultural groups that underpin the ideological conflict figure prominently ("lebanese", "greek", "anglo", "aussie"), as well as an increased 
concern about Islam. The major offline change across that time axis was the Cronulla riots. No other major changes occurred associated with the other nouns, other than how they were implicated in the riots. The results (Tables 1-2; Figure 1) identify how the riots are the independent variable during this change in online content and focus. By comparison 'Cronulla' was used, on average, 0.04 times per week (or once during 6 months) before the riots, making it clear that the riots represent one of the key focus areas of the community.

\section{Transformation of the group norms}

To examine how group norms might change overtime in relation to the local riots, we analysed the 100 most quoted posts in the Stormfront Downunder between 2001 and 2015. After the posts were extracted and divided into two categories (i.e., posts made before the riots, and posts made after the riots), we analysed their content using an approach derived from thematic analysis (Clarke and Braun, 2013). Based on this analysis, two main thematic categories in the content of group norms were identified:

a) Normative content about group boundaries - establishing 'who are our allies' and 'who are our enemies';

b) Normative content about collective self-definition - establishing 'who we are as a group'.

While the two broad thematic categories were found in both posts before and after the riots - suggesting similar concerns around group boundaries and self-definition - we found differences in how these normative categories were framed, that is, the arguments used to construct these norms are different. Table 4 shows the key thematic categories before and after the riots including some of the most illustrative extracts for each of these categories.

Norms about group boundaries. Our analysis suggests that before the riots members of the online community were mostly preoccupied with establishing group boundaries by clarifying the group attitudes towards perceived allies such as the British royals (see extract 1 in Table 4), and by using essentialist arguments - establishing group membership based on an 'evidence-based' assessment of Australians' ethnic origins. The content on norms about group boundaries before the riots seems to reflect a positioning of the group as an AngloSaxon nationalist group, and generally, the discussions about group boundaries is both more positively framed (in relation to allies rather than enemies) and more inward looking/oriented (identifying essentialist criteria for group membership).

However, the content discussed after the riots reflects a more specific positioning not in relation to allies, but to outgroups which are in general viewed as enemies of the group. After the riots, group discussions more directly refer to Muslim Australians. Specific references to the riots are made to build an argument for exclusion based on cultural incompatibilities (extract 2, Table 4). Ironically, an argument for strategic group inclusiveness is also made, that is, that group boundaries should become more flexible so that southern Europeans who share white supremacist (and specifically anti-Muslim) values can join the group. The argument is framed around shared ideological aspects such as whiteness, Christianity, and the perceived common goal of stopping any culturally non-white migration (extract 4).

Norms about collective self-definition. Before the riots, discussions of group self-definition seem to be taken again on a more inward focus, that is, the members of the community focus on group validation in relation to, for instance, appropriate markers of group identity (physical appearance and grooming that would conform to group prototypes) and broader ideological positioning in relation to beliefs about racism (extract 5). 
After the riots, however, the discussions are focused on ideological positioning of the group, but this being done in a more specified manner as, for instance, vis-a-vis particular outgroups, e.g., Asians and Muslims (extract 6). The extracts also illustrate differences in tone - the discussion about Asian outgroups (extract 6) is more neutral in tone and includes no direct hostility, while discussions about Middle Easterners and Muslims (extracts 2, 8, and 9) are arguably more negative and emotionally charged. It is interesting to observe that the framing of the arguments changed, so after the riots the group has a stronger outgroup focus. This aligns with the accumulating Islamophobia of these times, and the later emergence of other events, such as Pauline Hanson's return to power on anti-Muslim politics. It is also a strong reflection of the increasing political permissiveness of racism at the time, and of a decreased inhibition at being blatantly racist in the public sphere.

Table 4. Illustrative quotes suggesting changes in the main thematic categories in the most quoted posts in the forum before and after the riots 


\begin{tabular}{ll}
\hline Thematic categories before the riots & Thematic categories after the riots \\
\hline $\begin{array}{l}\text { Norms about group boundaries: attitudes to allies } \\
\text { (support for British royalty) }\end{array}$ & $\begin{array}{l}\text { Norms about group boundaries: attitudes to specific } \\
\text { outgroups (Muslims) }\end{array}$ \\
$\begin{array}{l}\text { 1.“(...) As we enter the 21st century Prince Harry is } \\
\text { heading off to Iraq once he graduates from Sandhurst } \\
\text { military college, to be with the guys on the front line. }\end{array}$ & $\begin{array}{l}\text { lebanese has been far more brutal and savage than that } \\
\text { dealt by a small number of angry Australians on }\end{array}$ \\
$\begin{array}{ll}\text { (...) I'm writing to PM Howard to request that 5-6 } & \text { sunday at Cronulla. This was expected, their culture } \\
\text { Aussie special forces cadre (perhaps more) have the } & \text { and psyche is more force and revenge oriented, they } \\
\text { honour of accompanying our prince into the field, as } & \text { strive to enforce their male ego and establish } \\
\text { dominance, coupled with the belief of superiority and } \\
\text { brothers in arms. That way (...) he will have Australia at } \\
\text { his side in more than just spirit.” }\end{array}$ & $\begin{array}{l}\text { cultural strength. (...) Basically they are not flexible } \\
\text { and tolerant enough to conform to the Australian way } \\
\text { of life.(...)” }\end{array}$
\end{tabular}

Norms about group boundaries: essentialist arguments

3. "It has taken me a surprisingly long time to gather together and verify enough statistics to make an attempt at calculating Australia's ethnic origins. The classifications I have used are mainly my own and I realise there may be some people who will consider them incorrect; but I've done my best. (...)"
Norms about group boundaries - making the identity more inclusive for like-minded people

4. "it is time for all the Maltese, the Italians, the Greeks, the Croats etc. to start joining these forums. is time to start coming together in a way we all have never really done before. because whats happenning to the whites in Australia is basically happenning in your own countries of origin, of which $i$ am sure alot of you have family over there. time for the anglos to ditch the use of the word wog and its time for mediterraneans to become more associated with the anglos. and together we can say to the gutless leaders of this country, NO MORE NON-WHITES! EUROPEAN AND WHITE MIGRATION ONLY! or else we can all cop what Malta is copping (...)

Response: (...) Most of these people are Christians and have no time for the muslims. (...) They have given much to Australia and Australia has been good in return. It is time to think of ONE NATION, ONE RACE, NO MORE NON-WHITE IMMIGRATION AND DEFINITELY NO NON-WHITE REFUGEES.”

Norms about self-definition - physical appearance (visible markers of identity)

5."I regard my self as white national but I keep my hair, I am 42 with short hair combed to the side. I have seen quite a few that shave there heads I have seen pictures of baron. What about you guys and for you guys that do shave your heads what are your motives for doing that."
Norms about self-definition - ideological positioning in relation to outgroups (Asian)

6. "Are proud white Australians against non whites living here? or are we just unhappy with immigrants not conforming to our way of life and our Aussie values? I'm currently working with an asian who likes to have a beer and watch the footy, and who I think is not such a bad bloke, he has good work ethics and supports his family well. Does this mean I'm starting to soften my attitude? Or do I just believe that all are welcome as long as they adopt Australian values?"
Norms about self-definition - broad ideological positioning

7. "What is Racism? Racism is the belief that human races exist, that these races possess different abilities and different characters, or natures, and that some races are better at some things than other races. Racists do not want to live in multi-racial societies. Instead, they want to live among their own kind."
Norms about self-definition: ideological positioning in relation to outgroups (anti-Muslim)

8. "the aussie flag has just been banned from sydney schools because apparently it "entices racial hatred" yet the muslim "hijab" is not banned"

9. "This identical conflict happened once before in Spain, our White people forced into all out victory in war or lose and be enslaved by Arab Muslims.(...)" 


\section{Collective emotions and consensus in the online the community}

Table 5 shows an extract from the computerised linguistic analysis (LIWC analysis, Pennebaker et al, 2007; 2015) for the 50 most active users over the period one year prior to one-year post riots. To increase the reliability of the analysis, only posts containing more than 20 words were included in the analysis (Boyd et al., 2016). As Table 5 shows, computerised linguistic analysis conducted on online communication before and after the riots shows significant changes in the categories capturing negative emotions such as 'anger' and 'swear words' increased in frequency of use, while the overall category 'negative emotions' stayed the same. Computerised linguistic analysis shows that the internal levels of consensus as indicated by variations in the linguistic category 'assent' stayed the same, while 'negation' and 'differentiation' categories significantly decreased (see also Table 5).

Table 5. LIWC word categories and their increase in their usage after the riots.

\begin{tabular}{lllllllll}
\hline $\begin{array}{l}\text { LIWC } \\
\text { Categories }\end{array}$ & $\begin{array}{l}\% \\
\text { Change }\end{array}$ & $t$ & $p$ & $S E$ & $\begin{array}{l}\text { Means } \\
\text { Pre-riots }\end{array}$ & $\begin{array}{l}\text { SD Pre- } \\
\text { riots }\end{array}$ & $\begin{array}{l}\text { Mean } \\
\text { Post- } \\
\text { riots }\end{array}$ & $\begin{array}{l}\text { SD Post- } \\
\text { riots }\end{array}$ \\
\hline Anger & 9.742 & 2.685 & 0.004 & 0.034 & 0.874 & 1.405 & 0.965 & 1.563 \\
Swear words & 29.822 & 4.836 & 0.000 & 0.017 & 0.220 & 0.668 & 0.302 & 0.845 \\
Negative affect & 2.881 & 1.201 & 0.115 & 0.052 & 2.121 & 2.209 & 2.183 & 2.272 \\
Assent & 3.104 & 0.468 & 0.320 & 0.018 & 0.267 & 0.778 & 0.275 & 0.771 \\
Differentiation & -5.248 & -2.854 & 0.002 & 0.059 & 3.311 & 2.521 & 3.143 & 2.535 \\
\hline
\end{tabular}

\section{Discussion}

This study provides evidence that the collective identity of the far-right online community Stormfront Downunder changes in relation significant intergroup conflict 'in real life'. Changes in the groups' main concerns and norms, collective emotions and levels of consensus within the community are examined using a mixed-method approach that combines the use of natural language processing tools, thematic analysis, and computerised linguistic analysis. Our analysis reveals that significant transformations in the collective identity of the online community can be observed following local racist riots underpinned by sharp ideological conflict. However, the first and most significant finding regards the amount times the word 'Cronulla' was used in the forum in the week and aftermath of the riots indicating that this was a significant event for Stormfront, even though it was not an event of their making.

Second, our analysis of the most used nouns before and after the riots indicates that there is a change from a focus on generic, exclusivist topics which are broadly aligned to (global) white supremacy principles (such as race, nationalistic values, outgroups such as Jews, etc.) to a more crystalised focus on (local) specific ethnic and religious out-groups. The focus on religious or cultural groups has been an emphasis of the new racism politics, but hitherto in Australian that had been on Asians, criticised as culturally inferior of incompatible (Dunn et al., 2004). The increased use of words related to particular outgroups (such as "Lebs", "wogs", and "Muslims") was accompanied by an increase in words suggestive of violence such as "bash", "violence", and swear words. Before the riots, we can observe a more general focus in a way that could apply to most white supremacist groups in the Western world - it is only the mention of Australia that can pinpoint the community to a geographical location. When examining the nouns that had the greatest increase in use after 
the riots, we can immediately see that more specific references to ethnic and religious groups coupled with aggressively charged words (e.g., "gangs", "evil", "scum"), indicating a clear change, not only in the main concerns of the group, but also in the general affective tone of communication. The commentary was picking up on an emergent Islamophobia that had also underpinned the media and political foment that lead up to and followed the riots. Pauline Hanson would adopt the same strategy in five years-time on her return to Parliament. The riots were a crucible for this change in language by Stormfront, which facilitated a growth in online membership and activity.

Thirdly, the thematic analysis of the 100 most quoted posts reveals changes in the group norms, in particular, in relation to how group boundaries are conceptualised and how group members define themselves as a collective entity. The analysis suggests that before the riots, the community would predominantly discuss norms about group boundaries in relation to attitudes to allies ('who is on our side' type of argument), and essentialist criteria of group inclusion (Haslam et al., 2006). Collective self-definitions were mostly concerned with establishing what visible markers of identity are required from members and arguments around the ideological bases of group membership (in relation to racism and other ideological points relevant for the group). The normative content has evolved after the riots to be more aligned with a highly focalised, unambiguous oppositional stance (against outgroup/s) evident when debating both norms about group boundaries and collective self-definition. The findings of this analysis are consistent with the previously discussed findings and suggest that the community has become more about strictly defined group boundaries designed to keep people out, rather than let people in (with the exception of the strategical argument of opening the group for ideologically aligned people who can provide strength by numbers), and self-definition through differentiation from outgroups. The identity content also becomes more clearly centred on opposition to Muslims.

Finally, the findings of the computerised linguistic analysis regarding changes in collective emotions and levels of consensus are mixed. That is, while the overall category 'negative emotions' did not change, it is significant that anger increased. In LIWC, the 'negative emotions' category includes anxiety and sadness related words which are suggestive of passivity and resignation. On the contrary, anger is often associated with a sense of injustice on the group's behalf which, together with commitment to the group and perceived group efficacy, is a precursor of collective action mobilisation (Duncan, 2012; Van Zomeren et al., 2008). Thus, it is plausible that anger as a collective emotion has had an energising role for the group members which over time was reflected in more sustained realworld activity which could have been associated with the gradual increase in far-right active groups in Australia and their levels of activity (Rydgren, 2018).

In relation to levels of consensus, while there was little change in the use of 'assent' words, 'differentiation' words decreased. These findings show that levels of agreement in the online communication roughly stayed the same before and after the riots, but levels of disagreement decreased. This is a subtle difference, but nevertheless it indicates a climate characterised by increased consensus. Thus, after the riots, the community seems to have experienced less disagreement, thus likely stronger attraction between members. This is consistent with findings of stronger structural cohesion of the group in the aftermath of the riots (Bliuc et al., 2016) and provides support for the argument that communication within information bubbles characterised by ideological homophily can increase polarization and radicalisation (Kaakinen et al., 2018).

\section{Conclusion}


The current study focuses on the effects of a local socio-political event on a specific ideologically-driven online community. A large amount of data (i.e., communications between group members over 14 years) was analysed using mixed methods, but to be fully confident about generalising these findings to other online communities, similar analyses should be conducted in other groups. In the Stormfront Downunder, the riots produced unprecedented levels of activity; no other offline events with effects close in magnitude were identified in the timeframe of the study. However, in other communities it may be that more than one key event affects the community, so examining these effects in future research could tell us more about how online communities are shaped by offline events and how in turn these communities may affect behaviours and collective action in the 'real-world'.

Overall, our findings suggest that the collective identity of this particular online community studied has significantly changed in the aftermath of strong intergroup conflict in the real-world. Our analysis shows strong associations of collective beliefs, emotions and levels of consensus in the online community to events 'in real life' and ultimately to the local political climate at the time, suggesting that that far-right online groups are sensitive (and perhaps reactive) to what happens in society, in particular, if the events are directly relevant to the group. The results suggest that the riots played a key role in unifying and giving purpose to supporters of white supremacism in Australia by helping them clarify and crystallise their collective beliefs and enhance their reach.

\section{References}

Alberici AI and Milesi P (2016) Online discussion, politicized identity, and collective action. Group Processes and Intergroup Relations 19: 43-59.

Awan I (2014) Islamophobia and Twitter: A typology of online hate against Muslims on social media. Policy and Internet 6: 133-150.

Barak A, Boniel-Nissim M and Suler J (2008) Fostering empowerment in online support groups. Computers in Human Behavior 24: 1867-1883.

Beirich H (2015) 20 Years of Hate. Southern Poverty Law Center Intelligence Reports; https://www.splcenter.org/fighting-hate/intelligence-report/2015/20-years-hate.

Best D, Bliuc AM, Iqbal M, Upton K and Hodgkins S (2018) Mapping social identity change in online networks of addiction recovery. Addiction Research and Theory 26: 1-11.

Bliuc AM, Best D, Iqbal M and Upton K (2017) Building addiction recovery capital through online participation in a recovery community. Social Science and Medicine 193: 110117.

Bliuc AM, Betts J, Faulkner N, Vergani M, Chow RJ and Iqbal M. Group Cohesion in Online White Supremacist Communities - Integrating Social Network and Computerised Linguistic Analyses (2016) Vox-Pol Mid-Project conference: Taking Stock of Research on Violent Online Political Extremism.

Bliuc AM, McGarty C, Badea C and Boza M (2018a) Enacting collective support for the European integration: Participation in pro-integration action and preference for specific transnational acculturation strategies. Journal of Community and Applied Social Psychology 28:15-28.

Bliuc AM, McGarty C, Hartley L and Muntele Hendres D (2012) Manipulating national identity: the strategic use of rhetoric by supporters and opponents of the 'Cronulla riots' in Australia. Ethnic and Racial Studies 35: 2174-2194.

Bliuc AM, McGarty C, Reynolds K and Muntele D (2007) Opinion-based group membership as a predictor of commitment to political action. European Journal of Social Psychology 37: 19-32. 
Bliuc AM, McGarty C, Thomas EF, Lala G, Berndsen M and Misajon R (2015) Public division about climate change rooted in conflicting socio-political identities. Nature Climate Change 5: 226-229.

Bliuc AM, Faulkner N, Jakubowicz A and McGarty C (2018b) Online networks of racial hate: A systematic review of 10 years of research on cyber-racism. Computers in Human Behavior 87: 75-86.

Bos L, Sheets P and Boomgaarden HG (2018) The Role of Implicit Attitudes in Populist Radical-Right Support. Political Psychology, 39: 69-87.

Boyd RL, Wilson SR, Pennebaker JW, Kosinski M, Stillwell DJ and Mihalcea R (2015) Values in words: Using language to evaluate and understand personal values. Paper presented at the ICWSM.

Briskman, L. (2017). The politics of state-sanctioned violence in Australia: racialized constructions of nation. In R. Mason (Ed.), Legacies of Violence: Rendering the Unspeakable Past in Modern Australia (pp. 11-29).

Clarke V and Braun V (2013) Teaching thematic analysis: Overcoming challenges and developing strategies for effective learning. The Psychologist 26: 120-123.

Duncan LE (2012) The psychology of collective action. In The Oxford handbook of personality and social psychology.

Dunn KM (2009) Performing Australian nationalisms at Cronulla. Lines in the sand: The Cronulla riots, multiculturalism and national belonging, pp.76-94.

Dunn KM, Forrest J, Burnley I and McDonald A (2004) Constructing racism in Australia. Australian Journal of Social Issues 39: 409-430.

Haslam N, Bastian B, Bain P and Kashima Y (2006) Psychological essentialism, implicit theories, and intergroup relations. Group Processes and Intergroup Relations 9: 6376.

Inglehart R and Norris P (2016) Trump, Brexit, and the rise of populism: Economic havenots and cultural backlash. HKS Faculty Research Working Paper Series RWP: 16026.

Ishii K and Ogasahara M (2006) Links between real and online networks: A comparative study of online communities in Japan and Korea. CyberPsychology, Behavior \& Social Networking 10: 252-257.

Kaakinen M, Sirola A, Savolainen I and Oksanen A (2018) Shared identity and shared information in social media: development and validation of the identity bubble reinforcement scale. Media Psychology, doi.org/10.1080/15213269.2018.1544910

Kamp A, Alam O, Blair K and Dunn K (2017) Australians' views on cultural diversity, nation and migration, 2015-16. Cosmopolitan Civil Societies: an Interdisciplinary Journal 9: 61-84.

Jakubowicz A, Dunn KM, Mason G, Paradies Y, Bliuc A-M, Bahfen, N, Atie, R, Connelly K (2017) Cyber Racism and Community Resilience, Palgrave Macmillan: Basingstoke.

Lawrence RG and Boydstun AE (2017) What we should really be asking about media attention to Trump. Political Communication 34: 150-153.

Livingstone A and Haslam SA (2008) The importance of social identity content in a setting of chronic social conflict: Understanding intergroup relations in Northern Ireland. British Journal of Social Psychology 47: 1-21.

Lee FL, Chen HT and Chan M (2017) Social media use and university students' participation in a large-scale protest campaign: The case of Hong Kong's Umbrella Movement. Telematics and Informatics 34: 457-469.

McGarty C, Thomas EF, Lala G, Smith LG and Bliuc AM (2014) New technologies, new identities, and the growth of mass opposition in the Arab Spring. Political Psychology 35: 725-740. 
Noble G and Poynting S (2010) White lines: The intercultural politics of everyday movement in social spaces. Journal of Intercultural Studies 31: 489-505.

Noble G (2009) Lines in the sand: The Cronulla riots, multiculturalism and national belonging. Institute of Criminology Press.

Odağ Ö, Uluğ ÖM and Solak N (2016) “Everyday I'm çapuling”: Identity and collective action through social network sites in the Gezi Park protests in Turkey. Journal of Media Psychology: Theories, Methods, and Applications 28: 148-156.

Oksanen A, Kaakinen M, Minkkinen J, Räsänen P, Enjolras B and Steen-Johnsen K (2018) Perceived Societal Fear and Cyberhate after the November 2015 Paris Terrorist Attacks. Terrorism and Political Violence, 1-20.

Pennebaker J W, Booth R and Francis ME (2007) Linguistic inquiry and word count: LIWC [Computer software]. Austin, TX: liwc. Net.

Postmes T (2015) Psychology: Climate change and group dynamics. Nature Climate Change 5:195.

Rydgren, J. (2018) The Oxford Handbook of the Radical Right. Oxford University Press.

Southern Poverty Law Centre (2017) Waning Storm: Stormfront.org Loses Its Domain. https://www.splcenter.org/hatewatch/2017/08/29/waning-storm-stormfrontorg-losesits-domain.

Turner JC and Reynolds KJ (2001) The social identity perspective in intergroup relations: Theories, themes, and controversies. Blackwell handbook of social psychology: Intergroup processes 4: 133-152.

Van Zomeren M, Postmes T and Spears R (2008) Toward an integrative social identity model of collective action: A quantitative research synthesis of three socio-psychological perspectives. Psychological Bulletin 134: 504-535.

Wojcieszak, M (2010) 'Don't talk to me': effects of ideologically homogeneous online groups and politically dissimilar offline ties on extremism. New Media and Society 12: 637-655.

Zhang Y, Wells C, Wang S and Rohe K (2017) Attention and amplification in the hybrid media system: The composition and activity of Donald Trump's Twitter following during the 2016 presidential election. New Media \& Society 20: 3161-3182.

\section{Acknowledgments}

Funding: The authors are grateful to the Australian Research Council, Australian Human Rights Commission, and the Victorian Health Promotion Foundation for funding this project.

Competing interests: There are no competing interests for any of the authors. 